For reservations notify the Pick Congress Hotel (address below) before October 13, 1978 in order to receive the special room rate. The hotel has reserved 80 rooms for HES members. For those reservations received before October 13 the hotel will charge $\$ 20.00$ for a single room and $\$ 28.00$ for a double (plus tax).

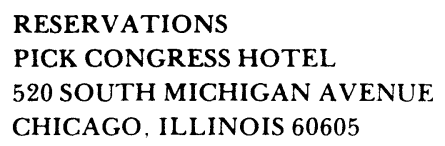

\title{
KINGDOM OF SAUDI ARABIA
}

\section{UNIVERSITY OF RIYADH COLLEGE OF EDUCATION}

\section{ARABIC-SPEAKING PH.D.'S ONLY!}

Applications are invited for faculty at all professorial ranks in Educational and Psychological specializations.

Competative salaries and benefits.

Send letter of application and curriculum vitae to:

The Dean, College of Education

University of Riyadh

P.O. Box 2458

Riyadh

SAUDI ARABIA 


\section{New York University Series in Education and Socialization in American History}

\section{SCHOOLED LAWYERS \\ A Study in the Clash of \\ Professional Cultures \\ By William R. Johnson}

The 20th-century university law school was born of a struggle between professors and practitioners. Using evidence gathered in a detailed study of the Wisconsin legal profession, Johnson argues that the emergence in the 19th century of a pattern of universitysponsored legal education was the critical factor in creating the modern law school and in shaping 20th-century legal culture.

256 pages, $\$ 15.00$

\section{THE REVOLUTIONARY COLLEGE}

American Presbyterian Higher

Education, 1707-1837

By Howard Miller

"This is a bold and imaginative work of history . . . of integrated social and cultural history such as has rarely been written . . Miller uses the history of Presbyterianism and Presbyterian efforts in higher education to illuminate, as no other historian quite has, America's emergence into the individualistic, competitive and democratic society of the 19th century."-Gordon S. Wood, Professor of History, Brown University

381 pages, $\$ 20.00$

Of related interest:

THE OPEN UNIVERSITY FROM WITHIN

By John Ferguson

165 pages, $\$ 10.00$

\author{
COLLEGIATE WOMEN \\ Domesticity and Career in \\ Turn-of-the-Century America \\ By Roberta Frankfort
}

This is an original analysis of the history of women's higher education based on a detailed study of the colleges of Bryn Mawr and Wellesley and the career patterns of their alumnae during the 19 th and early 20th centuries. Ms. Frankfort presents surprising evidence to show that after the first generation of collegiate women in America, these institutions collectively abandoned their commitment to helping women transcend domestic roles.

121 pages, $\$ 10.50$

THE CLASSLESS PROFESSION

American Schoolmen of the Nineteenth Century

By Paul Mattingly

"Mattingly's book is superlative in its exploration of the distinctive cultural qualities of the teaching profession."

-Joseph Kett, Review of Education

"What remains solid and permanently useful . . is his [Mattingly's] intellectual history of early leaders - the best such study to date."-David Tyack, Journal of American History

235 pages, $\$ 15.00$ cloth $\$ \$ 4.95$ paper

Of related interest:

\section{EDUCATION AND SOCIAL} CHANGE

Themes from Ontario's Past

By Michael B. Katz and

Paul H. Mattingly

"This collection of important essays ... will inform members of the Canadian historical community of the revolutionary changes in the writing of educational history that have taken place over the past ten years."-Histoire Sociale/Social History

324 pages, $\$ 15.00$ cloth, new paperback edition: $\$ 5.95$ 


\section{Pusey grades higher education.}

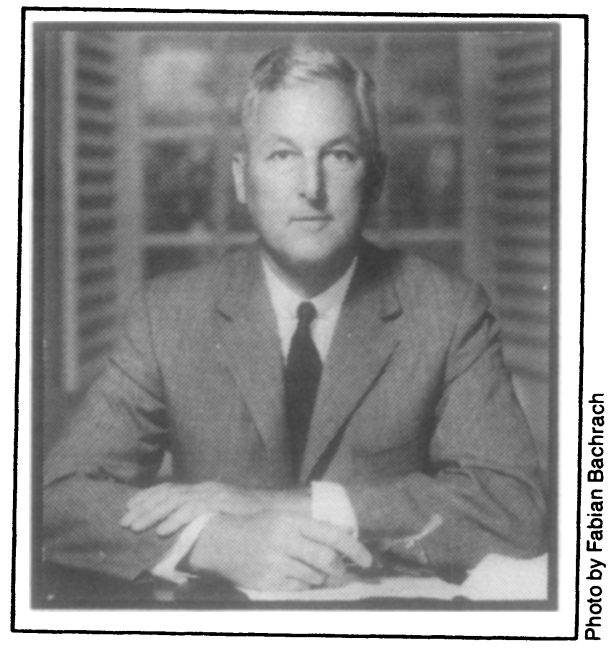

Nathan Pusey, President Emeritus of Harvard University, gives high marks to what he calls, "The most creative period in the history of higher education in the United States."

He cites many crucial changes in university education following World War II-such as the broadening of undergraduate curricula, burgeoning research activity, and increased availability to a greater percentage of the population - in a book filled with trenchant commentary and criticism.

If you're concerned with higher education, you must read this book.

\section{American Figher Fducation}

\section{8 - 1970}

A Personal Report

Nathan M. Pusey

$\$ 10.00$ 
